\title{
Variation of the hydraulic conductivity of Boom Clay under various thermal-hydro-mechanical conditions
}

Yong-Shang Ma ${ }^{\mathrm{a}, \mathrm{b}}$, Wei-Zhong Chen ${ }^{\mathrm{c} *}$, Hong-Dan $\mathrm{Yu}^{\mathrm{a}}$, Zhe Gong ${ }^{\mathrm{a}}$, Xiang-Ling Li ${ }^{\mathrm{d}}$

${ }^{a}$ State Key Laboratory of Geomechanics and Geotechnical Engineering, Institute of Rock and Soil

Mechanics, Chinese Academy of Science, Wuhan, Hubei 430071, China

${ }^{b}$ University of Chinese Academy of Science, Beijing 100049, China

${ }^{\mathrm{c}}$ Research Centre of Geotechnical and Structural Engineering, Shandong University, Jinan, Shandong 250061, China

${ }^{\mathrm{d}}$ European Underground Research Infrastructure for Disposal of Nuclear Waste in Clay Environment, EIG Euridice, (EURIDICE), 2400 Mol, Belgium

*Corresponding author: Wei-Zhong Chen

E-mail address: wzchen_SDU@163.com;

Tel.: +86-27-87199212 


\section{Abstract:}

In this paper, an experimental study is presented that intended to investigate (1) the anisotropy properties of hydraulic conductivity of Boom Clay, (2) the effect of heating-cooling cycle on the hydraulic conductivity and intrinsic permeability of Boom Clay, and (3) the effect of loading-unloading cycle on the hydraulic conductivity and intrinsic permeability of Boom Clay. Constant-head tests were carried out in a temperature-controlled triaxial cell. First, the anisotropic characteristic of hydraulic conductivity of Boom Clay with respect to its bedding was confirmed. The horizontal hydraulic conductivity (parallel to bedding) is larger than the vertical hydraulic conductivity (perpendicular to bedding). Second, there was a positive and reversible relationship between the hydraulic conductivity and temperature and a negative and irreversible relationship between the hydraulic conductivity and hydrostatic pressure. Specifically, for both horizontal and vertical hydraulic conductivity, the value at $80{ }^{\circ} \mathrm{C}$ is approximately 2.4 times larger than that at room temperature $\left(23{ }^{\circ} \mathrm{C}\right)$. However, it appears that the hydraulic conductivity is not sensitive to heating rate. Data analysis reveals that under variable temperature conditions, the changes in viscosity and density of water with temperature are the main factors affecting the change in hydraulic conductivity of Boom Clay with temperature, although other factors may have an effect to some extent. 
Keywords: Boom Clay; Hydraulic conductivity; Intrinsic permeability; THM effects; Heating-cooling cycle; Loading-unloading cycle;

\section{Introduction}

In Belgium, the Boom Clay is considered as one of the potential host rock formations for the deep geological disposal of high-level radioactive waste (HLW) because of its low hydraulic conductivity, swelling and self-healing capacity (Bernier at al., 2004). In the case of HLW disposal in the Boom Clay, thermo-hydro-mechanical (THM) perturbations are expected and they might affect the Boom Clay hydraulic conductivity. The THM coupled effect on the hydraulic conductivity of Boom Clay is a key factor for the repository design. Research relating to this issue has been a source of substantial interest for researchers in recent years.

A number of studies have been conducted to investigate these thermal effects on the hydraulic conductivity of saturated Boom Clay (Sultan, 1997; Delage et al., 2000; Monfared et al., 2012; Chen et al., 2014) and other clays (Morin and Silva, 1984 on illite and smectite; Towhata et al., 1993 on bentonite and MC clay, similar mineral content as kaolin; Houston and Lin, 1987 on illite; Cho et al., 1999 on bentonite; Villar and Lioret, 2004 on bentonite). These studies generally suggest that the hydraulic conductivity increases with increasing temperature. Cho et al. 
(1999) and Delage et al. (2000) proposed that the hydraulic conductivity increase is only attributable to the changes in viscosity of free water with temperature. However, there are different opinions regarding the comparison of the measured hydraulic conductivity and prediction on the basis of changes in the water properties with temperature (calculated with the experimentally measured hydraulic conductivity value at room temperature taking as a starting point). Towhata et al. (1993) analysed the influence of the temperature on the hydraulic conductivity of MC clay and bentonite and concluded that the increment of measured hydraulic conductivity with temperature was higher than that calculated by using changes in the water properties with temperature. Other studies on different clayey materials have shown that the increase in the hydraulic conductivity with temperature can be smaller than that predicted on the basis of the water viscosity change with temperature (Houston and Lin, 1987 on illite, Romero et al., 2001 on unsaturated Boom Clay and Villar and Lioret, 2004 on bentonite). Hence, further investigation is needed to clarify this issue.

Furthermore, substantial data (Wemaere et al., 1997; Bastiaens and Demarche, 2003; Bastiaens et al., 2007; Lima, 2011; Chen et al., 2011) indicate that Boom Clay has anisotropic properties. Dehandschutter et al. (2005) observed bedding of Boom Clay by SEM observations. Indeed, given the existence of sub-horizontal bedding planes, Boom Clay can be 
considered a transversely isotropic geomaterial (Chen et al., 2011; Yu et al., 2014). The anisotropic property of Boom Clay permeability has been investigated by in-situ experiments (Bastiaens et al., 2006). However, laboratory studies on the anisotropy property of the hydraulic conductivity of Boom Clay are rare.

In the laboratory, the hydraulic conductivity of low permeability clays is usually determined using the variable-head method or derived from the consolidation curves (Delage at al., 2000). In the present work, the hydraulic conductivity of Boom Clay during heating-cooling cycles and loading-unloading cycles was determined using constant-head method. Boom clay samples were extracted from the HADES facility in Mol (Belgium), the anisotropy properties were considered in specimen preparation. The test temperature ranged from room temperature to $80{ }^{\circ} \mathrm{C}$, which is a reasonable temperature variation interval of a future repository (Weetjens and Sillen, 2005). Two levels of confining pressures, $2.5 \mathrm{MPa}$ (close to its in situ effective stress) and $5.5 \mathrm{MPa}$ (close to its preconsolidation stress), are tested. The aim of this study is to present the experimental investigations of the effects of the heating-cooling and loading-unloading cycles on the hydraulic conductivity of Boom Clay with consideration for the anisotropy properties.

\section{Experimental set-up}

\subsection{Materials and sample preparation}


The tests have been carried out on samples, extracted at the depth of $223 \mathrm{~m}$ in the Boom Clay deposit, from the underground research laboratory HADES, at Mol site in Belgium. Boom Clay is a stiff clay, with a total volume porosity of around $39 \%$ and water content varying between 24 to $30 \%$. The dominant fraction (around 60\%) contains illite, smectite, illite-smectite mixed layers and kaolinite. The "non-clay minerals" are composed of quartz (25\%), feldspar with a little pyrite and calcite (Yu et al., 2012).

The hydraulic conductivities of Boom Clay measured through various testing techniques exhibit similar values in the order of $10^{-12} \mathrm{~m} / \mathrm{s}$ (Yu et al., 2013). To ensure a measurable flow in constant-head method in the dense plastic clay, smaller samples with standard diameter $(38 \mathrm{~mm})$ but reduced height $(10 \mathrm{~mm})$ were used. To take into account the anisotropy of Boom Clay, samples were manually trimmed with axes that were parallel (horizontal sample) and perpendicular (vertical sample) to the bedding. Sample re-saturation has been done under in-situ effective stress (2.5 MPa) using the same method as described by Yu et al. (2012) before permeability measurement. To avoid the presence of any gas, a vacuuming procedure was applied to the sample. The saturation time for Boom Clay was approximately 20 days until a satisfactory value of the Skempton coefficient B was obtained. Yu et al. (2012) supposed that the Skempton coefficient B would be less than 1.0 for stiff clays. The 
Skempton coefficient B of Boom Clay samples is stable at approximately 0.85-0.90 after several checkpoints (once a day) and it did not further increase. Therefore, as a kind of stiff clay, the value of 0.85 for saturation determination is acceptable.

\subsection{Experimental program}

Constant-head tests were carried out in a temperature-controlled triaxial testing machine (see Fig. 1), which was particularly designed to investigate the thermo-hydro-mechanical characteristics of Boom Clay. The device consists of a conventional triaxial apparatus and a temperature controller system. The confining pressure and back water pressure are applied by two hydraulic pressure generators and measured through hydraulic pressure transducers. The heater coil is installed on the outside of the cell. The power supplied to the coil is automatically adjusted using the temperature controller. Temperature is measured by the temperature sensor submersed in the cell fluid. This system allowed for a maximum temperature of $100{ }^{\circ} \mathrm{C}$ with an accuracy of $\pm 0.5^{\circ} \mathrm{C}$.

The experimental procedure, for both the horizontal sample and vertical sample, involves 8 stages after sample re-saturation (the first column of Table 1):

Stage 1: the sample was isostatically loaded to a confining pressure ( $\sigma_{1}=\sigma_{2}=\sigma_{3}=2.5 \mathrm{MPa}$, which is close to in situ effective stress).

Stage 2: a heating-cooling cycle $\left(23{ }^{\circ} \mathrm{C}\right.$, the room temperature, 
$\rightarrow 40 \rightarrow 60 \rightarrow 80 \rightarrow 60 \rightarrow 40 \rightarrow 23{ }^{\circ} \mathrm{C}$ ) with a heating-cooling rate of $0.3{ }^{\circ} \mathrm{C} / \mathrm{h}$ was applied.

Stage 3: the sample was isostatically loaded at a rate of $40 \mathrm{kPa} / \mathrm{h}$ from 2.5 $\mathrm{MPa}$ to $5.5 \mathrm{MPa}$ (close to preconsolidation stress).

Stage 4: another heating-cooling cycle that was the same as the previous one was applied.

Stages 5, 6, and 7: three additional heating-cooling cycles $\left(23 \rightarrow 80 \rightarrow 23{ }^{\circ} \mathrm{C}\right)$ with different heating-cooling rates $\left(1^{\circ} \mathrm{C} / \mathrm{h}, 5^{\circ} \mathrm{C} / \mathrm{h}\right.$, and $20^{\circ} \mathrm{C} / \mathrm{h}$, respectively) were applied.

Stage 8: the sample was isostatically unloaded back to $2.5 \mathrm{MPa}$ at a rate of $40 \mathrm{kPa} / \mathrm{h}$.

The detailed testing procedure is shown in Fig. 2. It would take more than two months to complete all eight stages for each sample. The stress states in which the constant-head tests are conducted are clearly marked in this figure (1 18). As long as the confining pressure or temperature reached the predetermined values in rows of Table 1, constant-head tests were carried out. Eighteen constant-head permeability measurements (the last column Table 1) were taken for both the horizontal and vertical samples. The back pressure was maintained at $1 \mathrm{MPa}$ during the entire test at the bottom of the sample, while the top porous stone was put in contact with the atmospheric pressure by unscrewing the pipe connected to the top of the sample. The high back pressure was necessary to obtain 
satisfactory precision when measuring the flow rate and, hence, the hydraulic conductivity (Delage et al., 2000). The injection fluid for the test is a synthetic Boom Clay water (SBCW).

\section{Test results}

\subsection{Permeability variation under heating-cooling cycles}

The volume of water injected as a function of time is given in Fig. 3. Despite the reduced sample height and high gradient applied, it still requires approximately ten hours to achieve a steady state of water flow that is consistent with that described by Delage et al. (2000). Delage et al. (2000) found that 10 hours is necessary to achieve permanent flow, and 15 hours is needed to obtain a satisfactory determination of the slope of the curve that corresponds to a constant flow. The characteristics of the steady state of water flow through Boom Clay at different temperatures and confining pressures are presented in Fig. 4. The steady flow duration at each temperature level is approximately 10 hours. A linear relationship can be obtained. The injected water volume within the same duration increases with increasing temperature indicating a higher hydraulic conductivity at higher temperature, while drops by one third were observed when the confining pressures increased from 2.5 to $5.5 \mathrm{MPa}$. The hydraulic conductivity was calculated by applying Darcy's law. The test results were compared with the results of previous studies in Fig. 5. The same trend was observed between the hydraulic conductivity and 
temperature in previous studies. Delage et al. (2000) measured the vertical hydraulic conductivity under a confining pressure $2.5 \mathrm{MPa}$ using constant-head method. The authors found an increase in the hydraulic conductivity from $2.5 \times 10^{-12} \mathrm{~m} / \mathrm{s}$ to $6.2 \times 10^{-12} \mathrm{~m} / \mathrm{s}$ with temperature increasing from $20{ }^{\circ} \mathrm{C}$ to $90{ }^{\circ} \mathrm{C}$. Similar results were reported by Chen et al. (2014), who measured the vertical hydraulic conductivity in a permeameter cell (non-loading system), with an increase in the hydraulic conductivity from $2.2 \times 10^{-12} \mathrm{~m} / \mathrm{s}$ to $7.4 \times 10^{-12} \mathrm{~m} / \mathrm{s}$ with increasing temperature from $23{ }^{\circ} \mathrm{C}$ to $80{ }^{\circ} \mathrm{C}$. Monfared et al. (2012) evaluated the permeability of Boom Clay (before and after shearing) using a transient method. Unfortunately, the permeability before shearing was only measured at room temperature (confining pressure of $3.25 \mathrm{MPa}$ ). There have been slight differences in the reported hydraulic conductivity values in different papers (Fig. 5), which could be acceptable because of the different test methods and boundary conditions.

Fig. 6 shows the variation of hydraulic conductivity of Boom Clay during two heating-cooling cycles. The figure shows that (1) at room temperature, the vertical $\left(\mathrm{k}_{\mathrm{v}}\right)$ and horizontal $\left(\mathrm{k}_{\mathrm{h}}\right)$ hydraulic conductivities are $1.73 \times 10^{-12} \mathrm{~m} / \mathrm{s}$ and $5.01 \times 10^{-12} \mathrm{~m} / \mathrm{s}$, respectively, which falls within the range of measured in situ hydraulic conductivity $\left(1.7-2.39 \times 10^{-12} \mathrm{~m} / \mathrm{s}\right.$ for $\mathrm{k}_{\mathrm{v}}$ and $4.1-5.2 \times 10^{-12} \mathrm{~m} / \mathrm{s}$ for $\mathrm{k}_{\mathrm{h}}$, Bastiaens et al.2006); (2) the anisotropic characteristic of hydraulic conductivity of Boom Clay with 
respect to its bedding was confirmed. The horizontal hydraulic conductivity (parallel to bedding) is 2.8 times larger than the vertical hydraulic conductivity (perpendicular to bedding); (3) during the heating-cooling cycle, there is a positive and reversible relationship between hydraulic conductivity and temperature, which Chen et al. (2014) also reported for damaged Boom Clay; (4) the hydraulic conductivity at $80^{\circ} \mathrm{C}$ is about 2.4 times larger than the one at room temperature; and (5) the horizontal (vertical) hydraulic conductivity drops by more than $30 \%$ when the confining pressure is increased from 2.5 to $5.5 \mathrm{MPa}$.

The intrinsic permeability, $K$, was computed according to:

$$
K=\frac{k \mu_{w}}{\gamma_{w}}
$$

where $k$ is the hydraulic conductivity, $\mu_{w}$ and $\gamma_{w}$ denote the water viscosity and unit weight of water respectively. The thermal variation of $\gamma_{w}$ and $\mu_{w}$ (Table 2) of "pure water" is available in Cho et al. (1999) and Delage et al. (2000), respectively. The variations of the intrinsic permeability of Boom Clay under different temperatures and confining pressures are shown in Fig. 7. It can be found that during the heating-cooling cycle, the intrinsic permeability decreases approximately 10 percent (for all tests) during the heating phase, then, it increases slightly during the cooling phase. Additionally, this phenomenon may be attributed to the thermal volume change behavior of Boom Clay. The plastic thermal contraction of samples during the heating phase results in 
a decrease in the intrinsic permeability.

\subsection{Permeability variation under loading-unloading cycles}

The variations of the hydraulic conductivity and intrinsic permeability at room temperature during the loading-unloading cycle are shown in Fig. 8 and 9. The results show that during the loading-unloading cycle, there is a negative and irreversible relationship between the hydraulic conductivity and hydrostatic pressure. Since the hydraulic conductivity is reversible during the heating-cooling phase (under both 2.5 and 5.5 MPa), the irreversible variation during the loading-unloading phase can be attributed to the mechanically-induced plastic volume change behavior. The irreversible volume contraction during the loading process irreversibly changes the permeability.

The different effects of the heating-cooling cycle and the loading-unloading cycle on the variation of intrinsic permeability can be clearly observed in Fig. 7 and 9. For instance, at a hydrostatic pressure of 2.5 $\mathrm{MPa}$, the horizontal intrinsic permeability changed from $4.80 \times 10^{-19}$ $\mathrm{m}^{2}$ to $4.20 \times 10^{-19} \mathrm{~m}^{2}$ upon heating $\left(23^{\circ} \mathrm{C}\right.$ to $\left.80{ }^{\circ} \mathrm{C}\right)$ and then slightly changed to $4.18 \times 10^{-19} \mathrm{~m}^{2}$ upon cooling to room temperature. This means that the intrinsic permeability varies by approximately $10 \%$ during the heating-cooling cycle within the temperature range of $23{ }^{\circ} \mathrm{C}$ and $80{ }^{\circ} \mathrm{C}$. By contrast, during the loading-unloading cycle within the range of 2.5 to 5.5 $\mathrm{MPa}$, the horizontal intrinsic permeability varies by more than $30 \%$. 
This indicates that the thermally-induced volume change within a reasonable temperature variation interval of a future repository (room temperature to $80{ }^{\circ} \mathrm{C}$ ) is much smaller compared to the mechanically-induced volume change. It is important to note that the stress levels used in the tests are close to the in situ effective stress (2.5 $\mathrm{MPa})$ and preconsolidation stress $(5.5 \mathrm{MPa})$. Hence, from the perspective of radioactive waste disposal engineering for the cases considered here, the thermally-induced intrinsic permeability change of Boom Clay is much smaller compared to the mechanically-induced intrinsic permeability change.

\subsection{Effect of heating rate on hydraulic conductivity}

The effect of heating rate on hydro-mechanical parameters of Boom Clay is very important, especially for the determination of heating rate of in-situ heating tests. Sultan (1997) suggested that the shape of the contraction curve was affected by the cooling rate. Test results reported by Cui et al. (2000) also show the cooling rate has a significant effect on the slope of the temperature $(T)$-thermally-induced volumetric strain $\left(\varepsilon_{v T}\right)$ diagram. Fig. 10 shows the variation of the hydraulic conductivity at $80^{\circ} \mathrm{C}$ reached at different heating rates obtained by this study (stages 5-7). The results show that the hydraulic conductivity stays constant with different heating rates, suggesting that the thermally-induced volume change behavior has less effect on the hydraulic conductivity of Boom 
Clay. The change in the hydraulic conductivity of Boom Clay with temperature may be mostly affected by changes in the viscosity and density of the pore fluid with temperature. Further investigations of this aspect are necessary, and a difference between the test results under drained and undrained conditions is expected.

\section{Discussion}

Under isothermal conditions, a widely used relationship between the hydraulic conductivity and physical properties of the pore fluid and clay mass for saturated clay is referred to as the Kozeny-Carman equation (Kozeny, 1927; Carman, 1937):

$$
k=C\left(\frac{g}{\mu_{w} \rho_{w}}\right) \frac{n^{3}}{(1-n)^{2} S^{2} G_{s}^{2}}
$$

where $C$ is an empirical parameter that is influenced by the tortuosity and shape of the flow channels, $g$ is the gravitational constant, $\mu_{w}$ is the dynamic viscosity of water, $\rho_{w}$ is the mass density of water, $n$ is the porosity of the clay mass, $S$ and $G_{s}$ denote the mass specific surface area and the specific weight of the solid material, respectively.

Similar to Kozeny-Carman equation, Towhata et al. (1993) suggested the hydraulic conductivity varies with temperature as

$$
\frac{k^{T}}{k^{T_{0}}}=\frac{f(T)}{f\left(T_{0}\right)} \frac{g(T)}{g\left(T_{0}\right)} \frac{h(T)}{h\left(T_{0}\right)}
$$

where $T_{0}$ denotes the reference temperature, $f$ denotes the effects of pore size and shape, $g$ denotes the effect of void ratio, and $h$ denotes the 
property of pore water at the corresponding temperature. However, Towhata et al. (1993) assumed the ratio of " $f$ " and " $g$ " in Eq. (3) equal to unity. That means the change of hydraulic conductivity can be predicted only considering the variation of water properties (viscosity and density) with temperature.

Based on Eq. (2), the variation of $S$ and $G_{s}$ can be neglected from the temperature range from $20^{\circ} \mathrm{C}$ to $90^{\circ} \mathrm{C}$ (Towhata et al., 1993), the hydraulic conductivity of clay at different temperatures $T$ can be represented as

$$
k^{T}=\frac{C^{T} \mu_{w}^{T_{0}} \rho_{w}^{T_{0}}\left(1-n^{T_{0}}\right)^{2}\left(n^{T}\right)^{3}}{C^{T_{0}} \mu_{w}^{T} \rho_{w}^{T}\left(1-n^{T}\right)^{2}\left(n^{T_{0}}\right)^{3}} k^{T_{0}}
$$

Eq. (4) indicates that the changes in the physical properties of water are not the only ones that influence the changes in the hydraulic conductivity with temperature. As the temperature increases, the thermal effects result in regrouping of the arrangement of clay particles, altering the clay fabric and porosity redistribution (Romero et al., 2001). Pusch and Güven (1990) observed the produce of larger voids between clay particles during heating by using AEM (Analytical Electron Microscopy). Additionally, the absorbed water may degenerate into free water under thermal loading (Derjaguin et al., 1986). The tortuosity and shape of the flow channels may have changed as a result of the above phenomenon, which is also the case for the values of $C$ and $n$. Furthermore, the porosity would also be influenced by the thermally-induced volume change 
behavior (Delage et al., 2000).

In order to separate these effects, the influence of the variation of the water physical properties with temperature on the hydraulic conductivity has been further investigated. The hydraulic conductivity of Boom Clay was predicted only considering the variation of water viscosity and density (Table 2), by taking the hydraulic conductivity experimentally measured at room temperature as a starting point. Fig. 11 shows the comparison between the hydraulic conductivity determined experimentally and those predicted on the basis of water viscosity and density changes. The figure confirms that the changes of water properties are the main driving factors for the variation of the hydraulic conductivity of Boom Clay with temperature.

However, it is worth noting that the increase in hydraulic conductivity with temperature obtained experimentally is slightly lower than that predicted on the basis of water viscosity and density changes. These results are similar to the results reported by Houston and Lin (1987) on illite and Villar et al. (2004) on bentonite, although Towhata et al. (1993) found that the changes of hydraulic conductivity of MC clay and bentonite with temperature are higher than those predicted on the basis of water viscosity changes. Based on Eq. (4), the discrepancy between the hydraulic conductivity experimentally measured and predicted may be attributed to the changes of clay porosity and flow channels properties 
with temperature. Moreover, the above described discrepancies may also partly be due to the differences in the experimental materials and boundary conditions.

The predictions of Eq. (3) and Eq. (4) were compared in Fig. 12. The variation of parameters at different temperatures in Eq. (3) and Eq. (4) is shown in Table 3 . The changes of hydraulic conductivity and clay porosity with temperature is measured experimentally by Delage et al. (2000). It is important to note that Towhata et al. (1993) assumed that the ratio of " $f$ " and " $g$ " in Eq. (3) is equal to unity, and the ratio of " $C$ " in Eq. (4) is at present assumed equal to unity. Obviously, Eq. (4) can better predict the change of hydraulic conductivity with temperature. Eq. (3) overestimates the values of hydraulic conductivity, because it is predicted only considering the variation of water properties (viscosity and density) with temperature, and assuming that the clay porosity remains constant.

\section{Conclusions}

Constant-head tests were carried out on Boom Clay samples under various hydrostatic pressures with heating-cooling cycles. The anisotropy properties were considered in specimen preparation. The following results can be deduced from these experiments:

(1) The measured vertical $\left(\mathrm{k}_{\mathrm{v}}\right)$ and horizontal $\left(\mathrm{k}_{\mathrm{h}}\right)$ hydraulic conductivities are $1.73 \times 10^{-12} \mathrm{~m} / \mathrm{s}$ and $5.01 \times 10^{-12} \mathrm{~m} / \mathrm{s}$, respectively, which falls within the range of the measured in situ hydraulic conductivity. 
(2) During heating-cooling cycles, there is a positive and reversible relationship between the hydraulic conductivity and temperature. The hydraulic conductivity at $80^{\circ} \mathrm{C}$ is approximately 2.4 times higher than that at room temperature. The increment of hydraulic conductivity with temperature is slightly lower than that predicted on the basis of water viscosity and density changes. The discrepancy between the experimentally measured and predicted hydraulic conductivities may be attributed to the changes of clay porosity and properties of the flow channels with temperature.

(3) The intrinsic permeability slightly decreases with increasing temperature. From the perspective of radioactive waste disposal engineering, the thermally-induced intrinsic permeability change of Boom Clay seems to be much smaller than the mechanically-induced intrinsic permeability change.

(4) During the loading-unloading cycle, there is a negative and irreversible relationship between the hydraulic conductivity and hydrostatic pressure.

(5) The hydraulic conductivity does not seem to be affected by the different heating rates.

These experimental results provide additional information for assessing the variation of hydraulic conductivity of Boom Clay with temperature and pressure changes, which is an important parameter for the repository 
performance assessment during the whole life of a repository, from construction to the heating and cooling phases. The anisotropic property of the Boom Clay permeability has been validated, which builds up our confidence in the hypothesis about the Boom Clay anisotropy. However, further investigations to clarify the THM coupled impact on the permeability of sheared Boom Clay and the self-sealing properties are still needed.

Acknowledgments The authors gratefully acknowledge the financial support of the National Science Foundation for Distinguished Young Scholars (No.51225902), the Natural Science Foundation of China under grant No.51479190 and EURIDICE (European Underground Research Infrastructure for Disposal of nuclear waste In Clay Environment, Mol, Belgium), which contributed to the work presented in this paper. The authors are also grateful to the editor and reviewers for their valuable comments, which have substantially improved this paper.

\section{References}

Baldi, G., Hueckel, T., Pellegrini, R., 1988. Thermal volume changes of the mineral-water system in low-porosity clay soils. Canadian geotechnical journal 25(4): 807-825.

Bastiaens, W., Bernier, F., Li, X.L., 2006. An overview of long-term HM measurements around HADES URF. Proceedings of International Symposium on multiphysics coupling and long-term behaviour in rock mechanics, Lieege, 15-26.

Bastiaens, W., Bernier, F., Li, X.L., 2007. SELFRAC: experiments and conclusions on fracturing, self-healing and self-sealing processesin clays. Physics and Chemistry of the Earth, Parts 
A/B/C 32(8): 600-615.

Bastiaens, W., Demarche, M., 2003. The extension of the URF HADES: realization and observations. WM'03 conference, February 23-27, Tucson, AZ.

Bernier, F., Demarche, M., Bel, J., 2004. The Belgian demonstration programme related to the disposal of high level and long lived radioactive waste: achievements and future works. WM'04 Conference, February 29 - March 4, Tucson, AZ WM-4324.

Campanella, R.G., Mitchell, J.K., 1968. Influence of temperature variations on soil behavior. Journal of the Soil Mechanics and Foundations Division 94(SM3):709-734.

Carman, P.C., 1937. Fluid flow through granular beds. Transactions-Institution of Chemical Engineers 15: 150-166.

Chen, G.J., Maes, T., Vandervoort, F., Sillen, X., Van Marcke, P., Honty, M., Vanderniepen, P., 2014. Thermal Impact on Damaged Boom Clay and Opalinus Clay: Permeameter and Isostatic Tests with $\mu \mathrm{CT}$ Scanning. Rock Mechanics and Rock Engineering 47(1):87-99.

Chen, G.J., Sillen, X., Verstricht, J., Li, X.L., 2011. ATLAS III in situ heating test in Boom clay: field data, observation and interpretation. Computers and Geotechnics 38(5): 683-696.

Cho, W.J., Lee, J.O., Chun, K.S., 1999. The temperature effects on hydraulic conductivity of compacted bentonite. Applied clay science 14(1): 47-58.

Cui, Y.J., Sultan, N., Delage, P., 2000. A thermomechanical model for saturated clays. Canadian Geotechnical Journal 37(3): 607-620.

Dehandschutter, B., Vandycke, S., Sintubin, M., Vandenberghe, N., Wouters, L., 2005. Brittle fractures and ductile shear bands in argillaceous sediments: inferences from Oligocen Boom clay (Belgium). Journal of Structural Geology 27(6): 1095-1112. 
Delage, P., Sultan, N., Cui, Y.J., 2000. On the thermal consolidation of Boom Clay. Canadian Geotechnical Journal 37:343-354.

Derjaguin, B.V., Kasasev, V.V., Khromova, E.N., 1986. Thermal expansion of water in fine pores. Journal of colloid and interface science 106:586- 587 .

Houston, S.L., Lin, H.D., 1987. A thermal consolidation model of pelagic clays. Marine Georesources \& Geotechnology 7(2): 79-98.

Kozeny, J., 1927. Über kapillare Leitung des Wassers im Boden:(Aufstieg, Versickerung und Anwendung auf die Bewässerung). Hölder-Pichler-Tempsky.

Lima, A., 2011. Thermo-hydro-mechanical behaviour of two deep Belgian clay formations: Boom and Ypresian Clays. PhD thesis, Universitat Politècnica de Catalunya, Barcelona, Spain, p 253.

Monfared, M., Sulem, J., Delage, P., Mohajerani, M., 2012. On the THM behaviour of a sheared Boom Clay sample: application to the behaviour and sealing properties of the EDZ. Engineering Geology 124:47-58.

Morin, R., Silva, A.J., 1984. The effects of high pressure and high temperature on some physical properties of ocean sediments. Journal of Geophysical Research: Solid Earth (1978-2012), 89(B1): 511-526.

Plum, R.L., Esrig, M.I., 1969. Some temperature effects on soil compressibility and pore water pressure. Highway Research Board Special Report, 103.

Pusch, R., Güven, N., 1990. Electron microscopic examination of hydrothermally treated bentonite clay. Engineering Geology 28(3): 303-314.

Romero, E., Gens, A., Lloret, A., 2001. Temperature effects on the hydraulic behaviour of an 
unsaturated clay. Geotechnical \& Geological Engineering 19(3-4): 311-332.

Sultan, N., 1997. Etude du comportement thermo-mécanique de l'argile de Boom: expériences et modélisation. PhD thesis, Ecole Nationale des Ponts et Chaussées, p 217.

Sultan, N., Delage, P., Cui, Y.J., 2002. Temperature effects on the volume change behaviour of Boom Clay. Engineering Geology 64(2): 135-145.

Towhata, I., Kuntiwattanakul P., Seko I., Ohishi K., 1993. Volume change of clays induced by heating as observed in consolidation tests. Soils and Foundations 33 (4):170 - 183.

Villar, M.V., Lloret, A., 2004. Influence of temperature on the hydro-mechanical behaviour of a compacted bentonite. Applied clay science 26(1): 337-350.

Weetjens, E., Sillen, X., 2006. Thermal analysis of the supercontainer concept: 2D axisymmetric heat transport calculations. SCK· CEN Report, 60.

Wemaere, I., Marivoet, J., Labat, S., Beaufays, R., Maes, T., 1997. Core manipulations and determination of hydraulic conductivities in the laboratory. Geological disposal of high-level and long lived radioactive waste. Waste \& Disposal Department SCK CEN, Mol, Belgium.

Yu, H.D., Chen, W.Z., Jia, S.P., Cao, J.J., Li, X.L., 2012. Experimental study on the hydro-mechanical behavior of Boom Clay. International Journal of Rock Mechanics and Mining Sciences 53: 159-165.

Yu, H.D., Chen, W.Z., Li, X.L., Sillen, X., 2014. A Transversely isotropic damage model for boom clay. Rock Mechanics and Rock Engineering 47(1): 207-219.

Yu, L., Rogiers, B., Gedeon, M., Marivoet, J., Craen, M.D., Mallants, D., 2013. A critical review of laboratory and in-situ hydraulic conductivity measurements for the Boom Clay in Belgium. Applied clay science 75: 1-12. 
Table 1 THM path for the constant-head test

\begin{tabular}{|c|c|c|c|c|}
\hline $\begin{array}{l}\text { Experimental } \\
\text { stage }\end{array}$ & Phase & $\begin{array}{l}\text { Hydrostatic pressure } \\
(\mathrm{MPa})\end{array}$ & $\begin{array}{c}\text { Temperature } \\
\left({ }^{\circ} \mathrm{C}\right) \\
\end{array}$ & $\begin{array}{l}\text { Constant-head } \\
\text { testing sequences }\end{array}$ \\
\hline 1 & & 2.5 & 23 & 1 \\
\hline \multirow[t]{6}{*}{2} & Heating 1 & 2.5 & 40 & 2 \\
\hline & & 2.5 & 60 & 3 \\
\hline & & 2.5 & 80 & 4 \\
\hline & Cooling 1 & 2.5 & 60 & 5 \\
\hline & & 2.5 & 40 & 6 \\
\hline & & 2.5 & 23 & 7 \\
\hline 3 & Loading & 5.5 & 23 & 8 \\
\hline \multirow[t]{6}{*}{4} & Heating 2 & 5.5 & 40 & 9 \\
\hline & & 5.5 & 60 & 10 \\
\hline & & 5.5 & 80 & 11 \\
\hline & Cooling 2 & 5.5 & 60 & 12 \\
\hline & & 5.5 & 40 & 13 \\
\hline & & 5.5 & 23 & 14 \\
\hline \multirow[t]{2}{*}{5} & Heating 3 & 5.5 & 80 & 15 \\
\hline & Cooling 3 & 5.5 & 23 & \\
\hline \multirow[t]{2}{*}{6} & Heating 4 & 5.5 & 80 & 16 \\
\hline & Cooling 4 & 5.5 & 23 & \\
\hline \multirow[t]{2}{*}{7} & Heating 5 & 5.5 & 80 & 17 \\
\hline & Cooling 5 & 5.5 & 23 & \\
\hline 8 & Unloading & 2.5 & 23 & 18 \\
\hline
\end{tabular}


Table 2 Variation of viscosity and density of pure water with temperature

\begin{tabular}{ccccc}
\hline Temperature $\left({ }^{\circ} \mathrm{C}\right)$ & 23 & 40 & 60 & 80 \\
\hline Viscosity $\left(10^{-3} \mathrm{~Pa} \cdot \mathrm{sec}\right)$ & 0.9579 & 0.6560 & 0.4688 & 0.3565 \\
Density $\left(\mathrm{g} / \mathrm{cm}^{3}\right)$ & 0.998 & 0.992 & 0.983 & 0.972 \\
\hline
\end{tabular}

Table 3 Variation of parameters at different temperatures in Eq. (3) and Eq. (4)

\begin{tabular}{cccccc}
\hline Temperature $\left({ }^{\circ} \mathrm{C}\right)$ & 20 & 60 & 70 & 80 & 90 \\
\hline Water viscosity $\left(10^{-3} \mathrm{~Pa} \cdot \mathrm{sec}\right)$ & 1.002 & 0.6560 & 0.4688 & 0.3565 & 0.3165 \\
Water density $\left(\mathrm{g} / \mathrm{cm}^{3}\right)$ & 0.998 & 0.983 & 0.978 & 0.972 & 0.965 \\
& & & & & 37.2 \\
Clay porosity $(\%)$ & 39.0 & 38.3 & 38.1 & 37.7 & \\
\hline
\end{tabular}




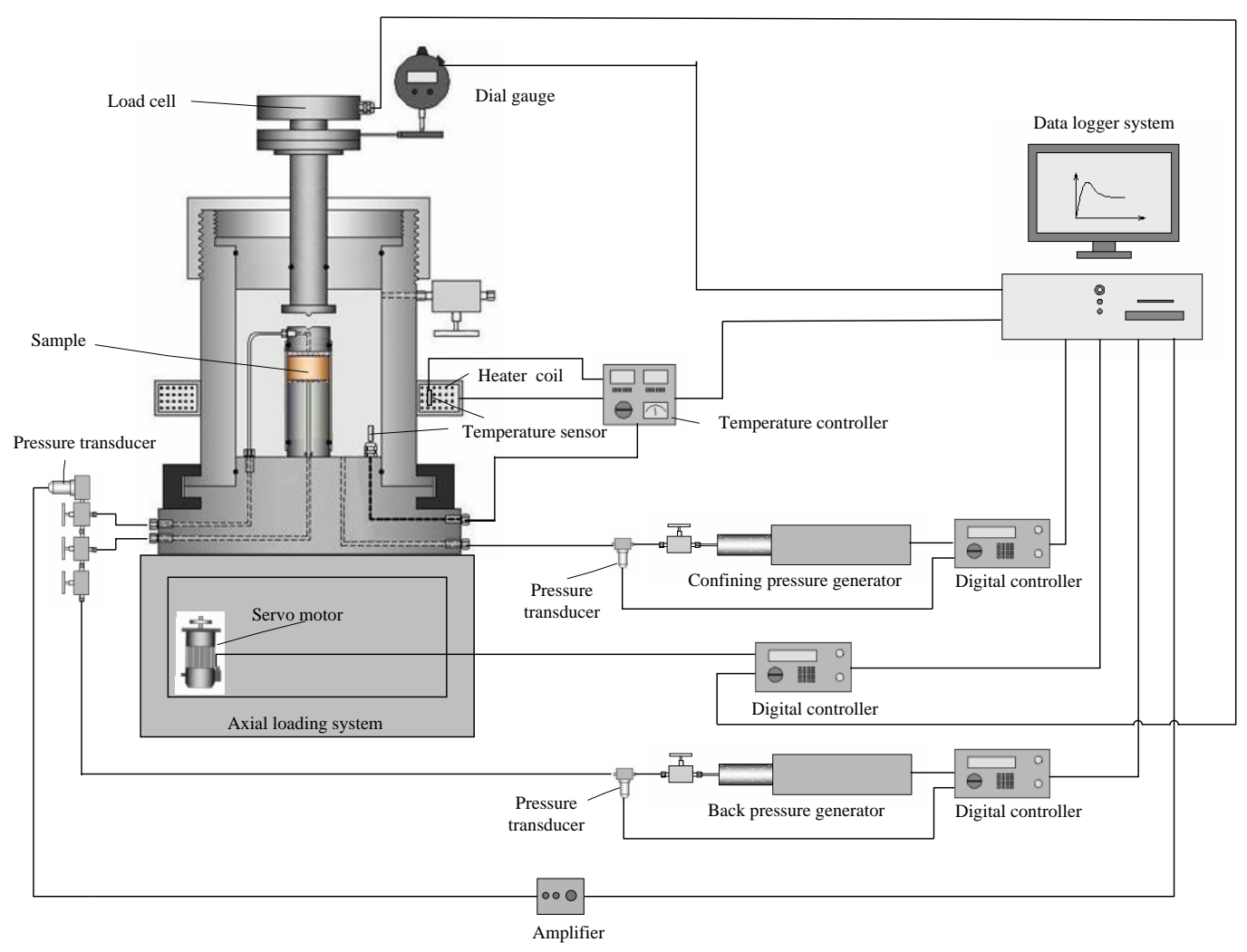

Fig. 1 Schematic diagram of the temperature-controlled triaxial cell

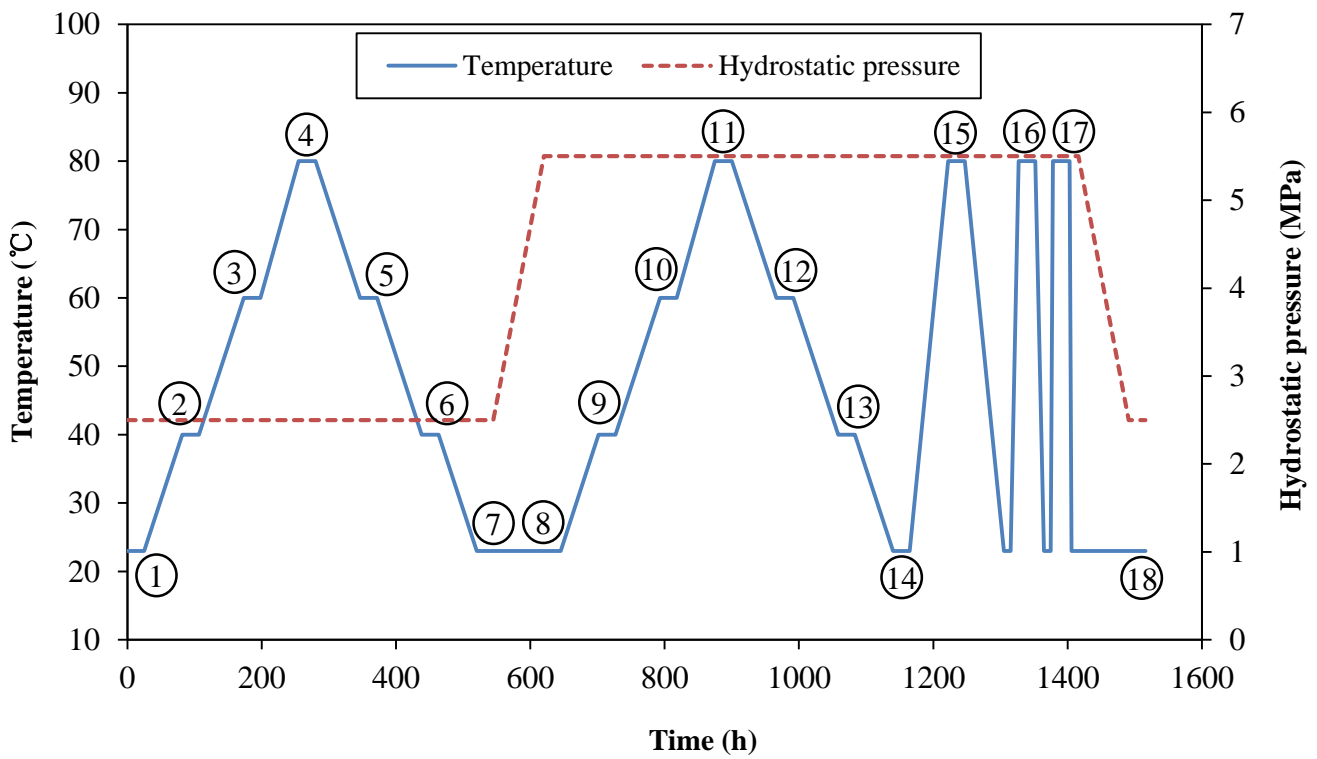

Fig. 2 Heating-cooling and loading-unloading procedures of constant-head test 


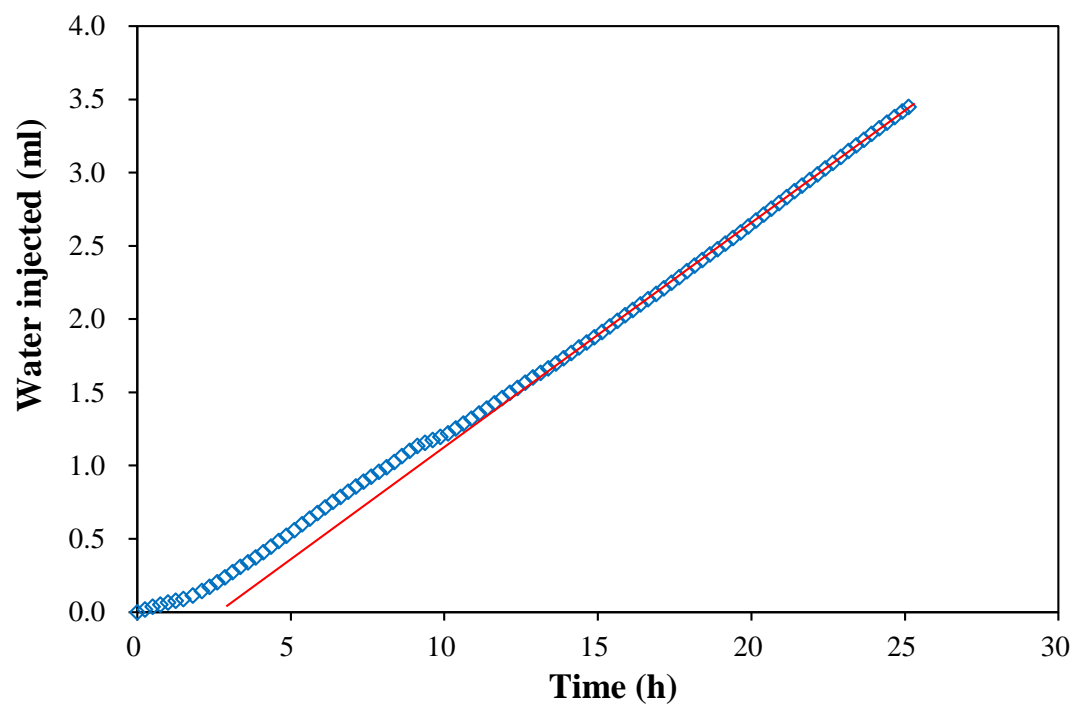

Fig. 3 Volume of water injected during a permeability test 


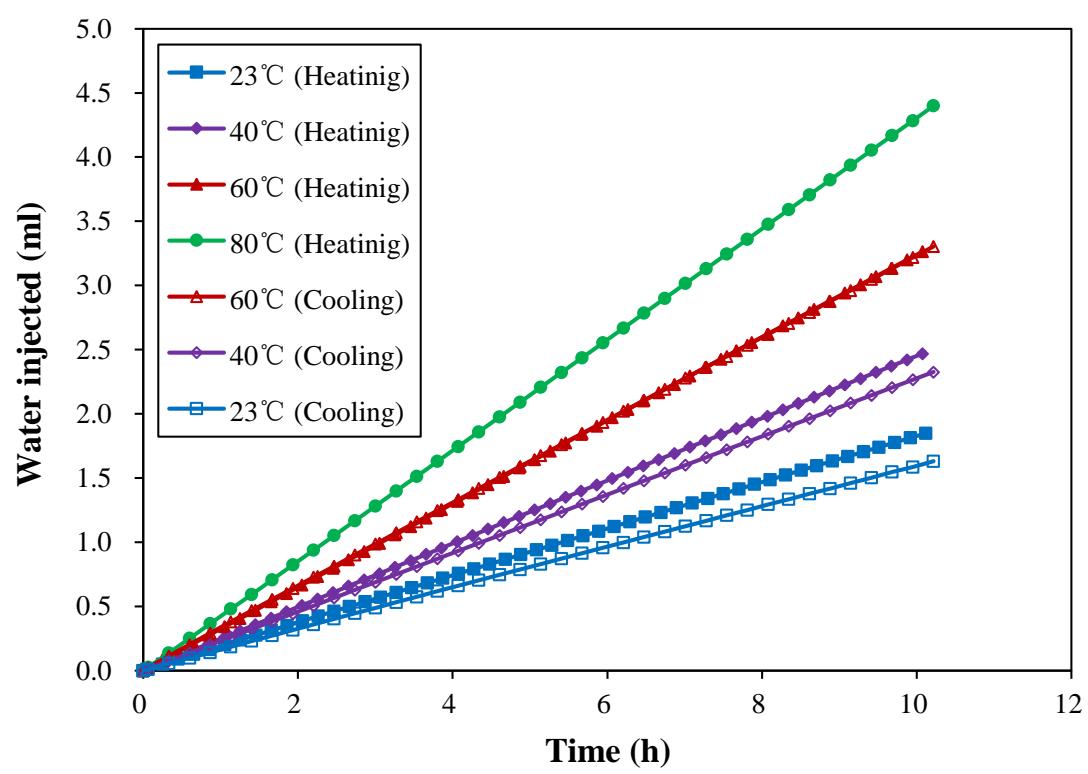

(a) Horizontal, 2.5 MPa

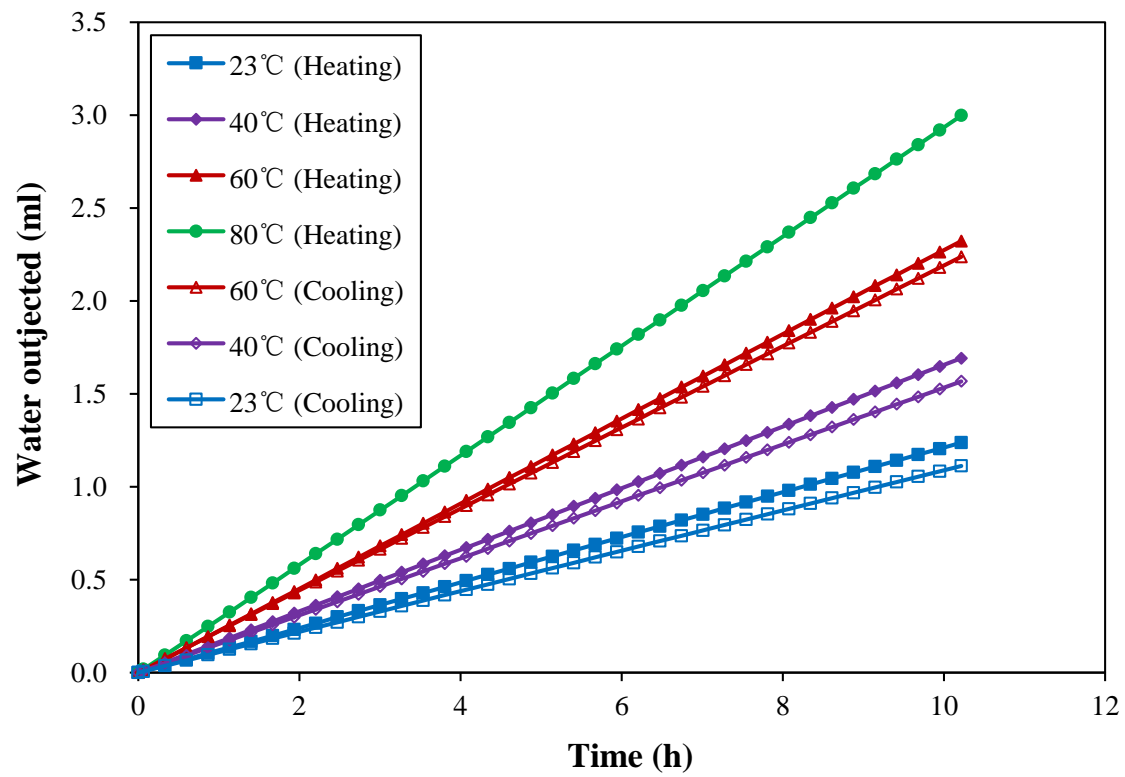

(b) Horizontal, 5.5 MPa 


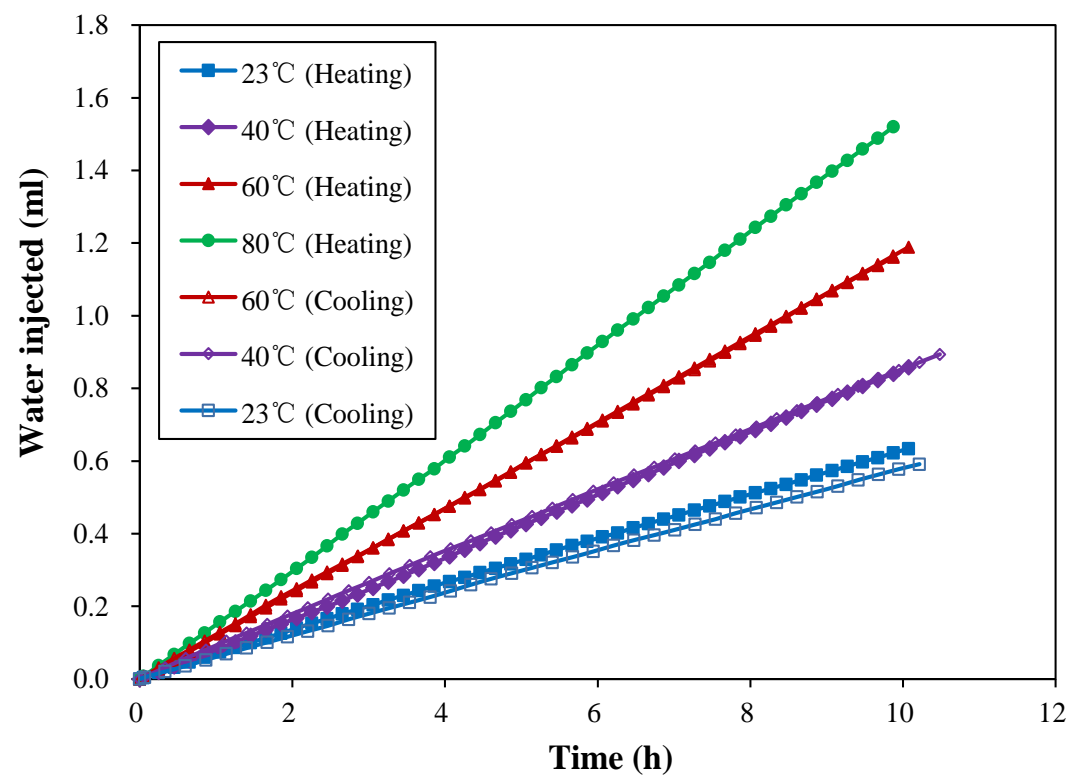

(c) Vertical, 2.5 MPa

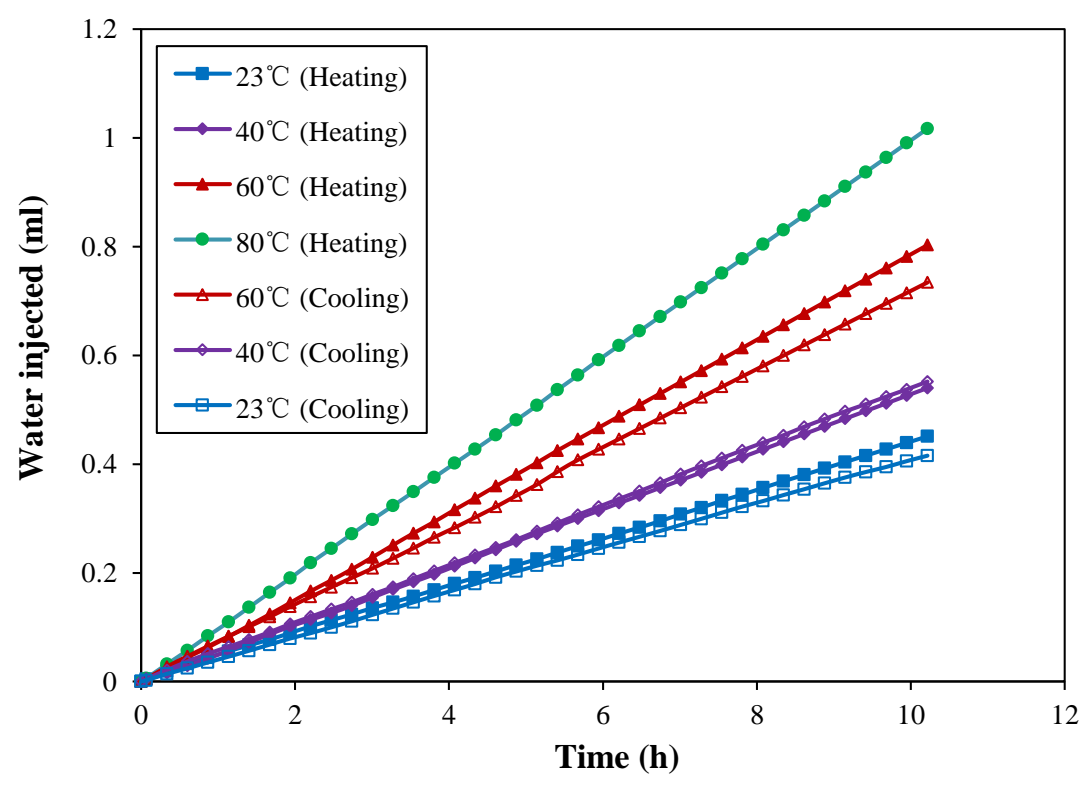

(d) Vertical, 5.5 MPa

Fig. 4 Injected water flow-time relationships of steady state experiments at different temperatures and confining pressures 


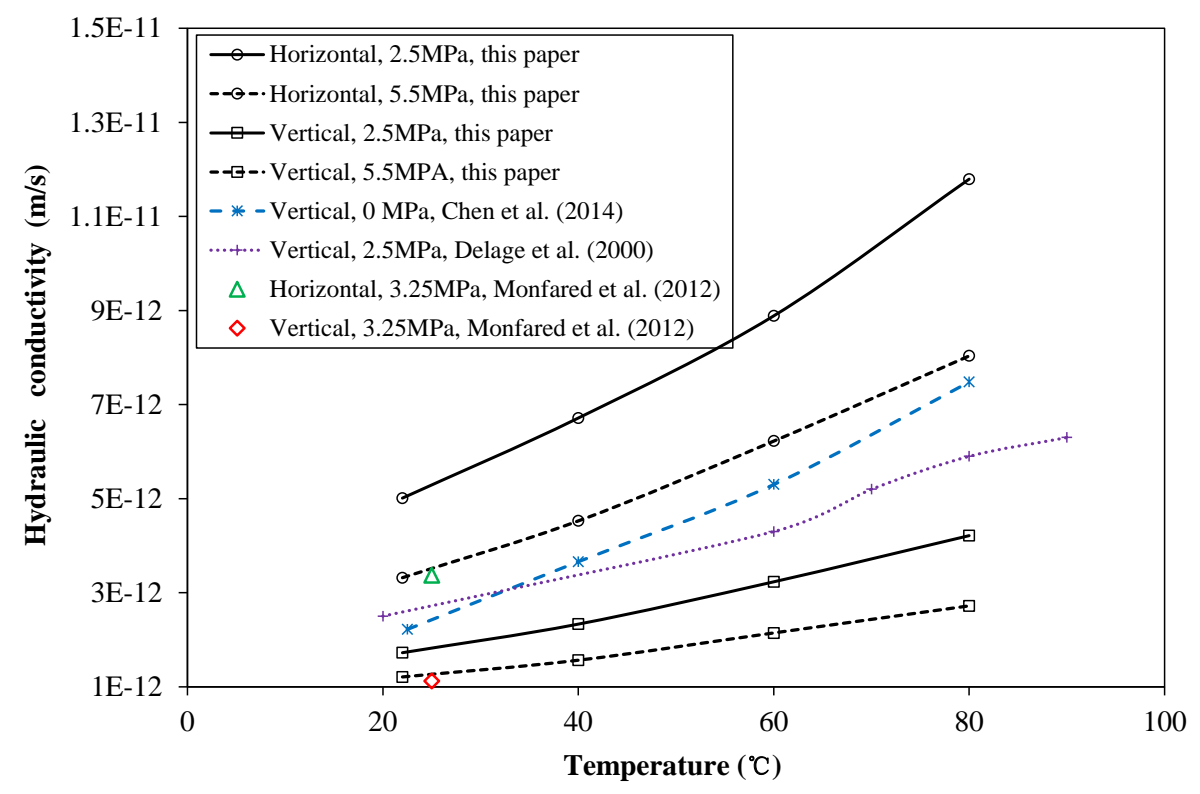

Fig. 5 Comparison of the hydraulic conductivity measured in this paper and the results of previous studies (Delage et al., 2000; Monfared et al., 2012; Chen et al., 2014) 


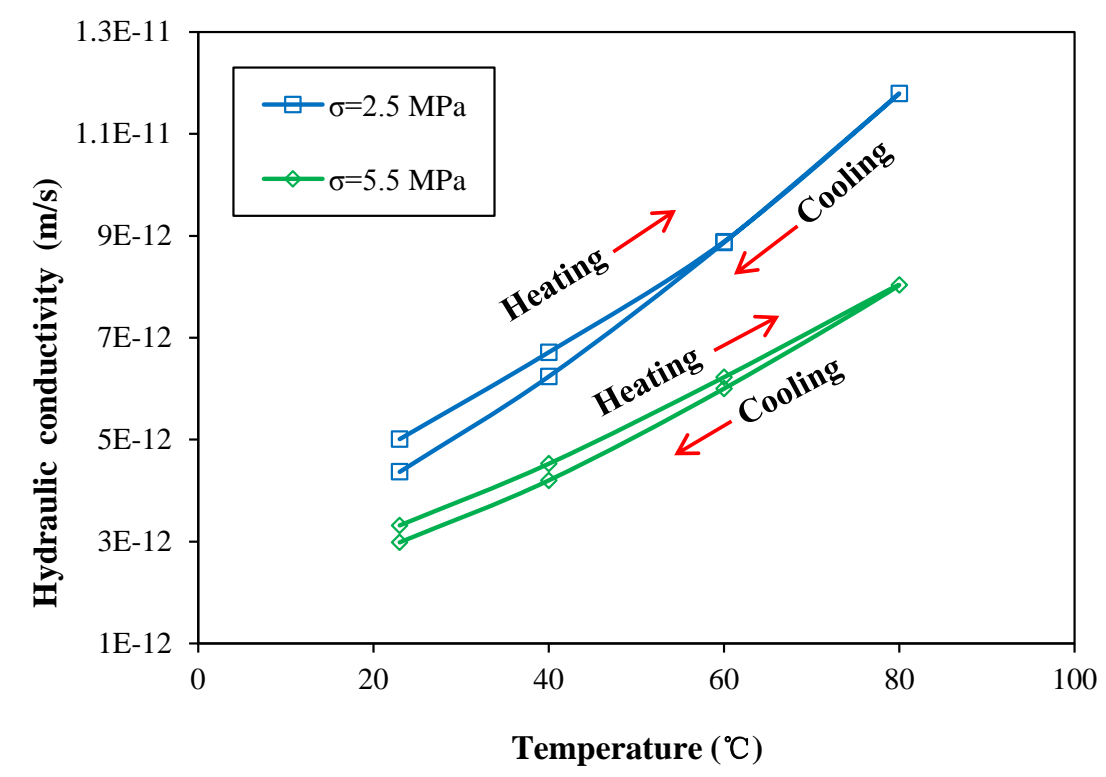

(a) Horizontal

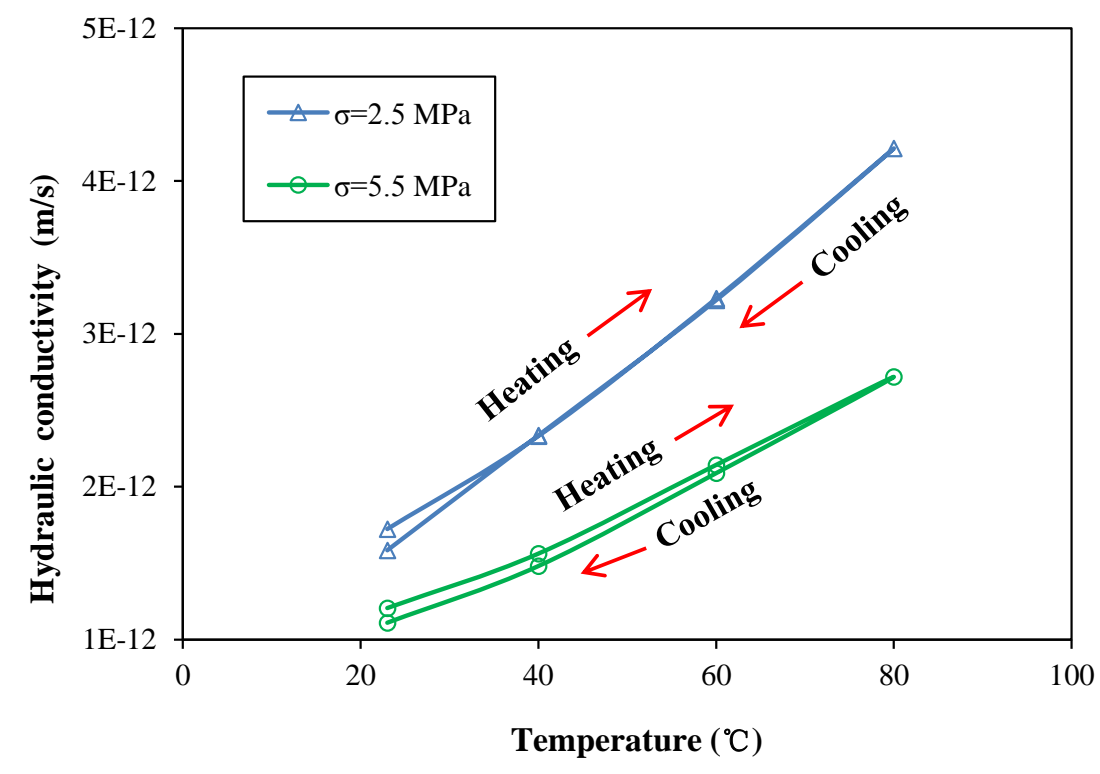

(b) Vertical

Fig. 6 Variation of the hydraulic conductivity during heating-cooling cycles 


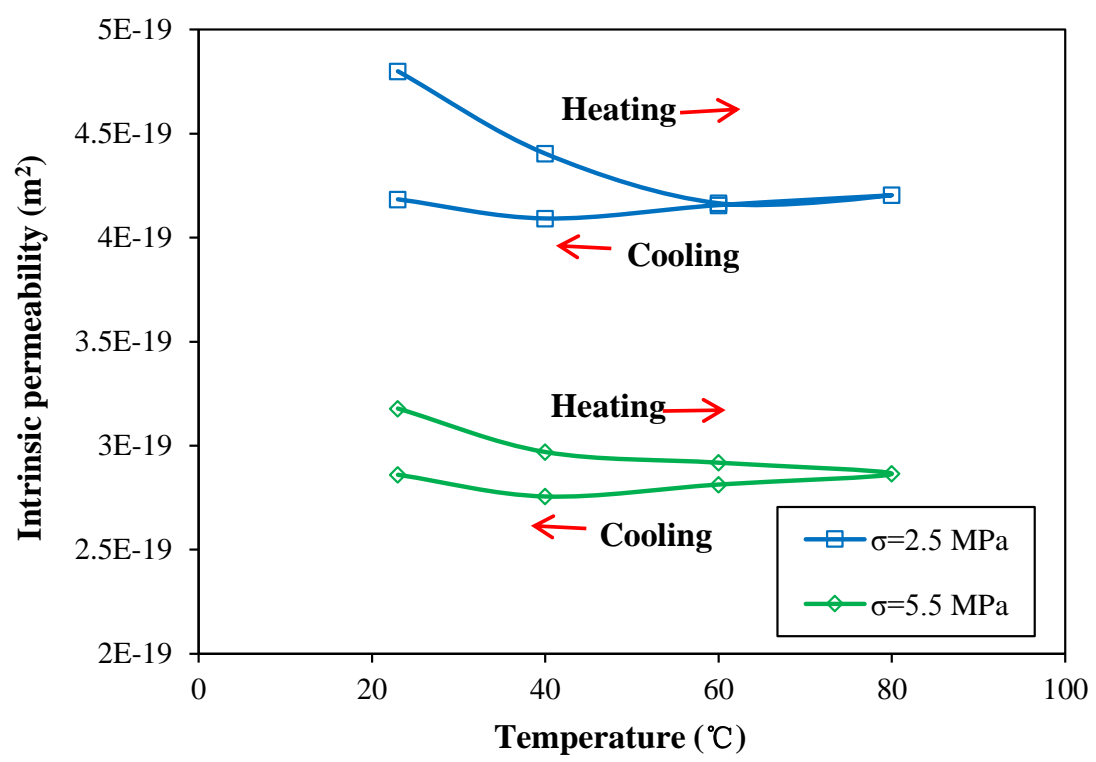

(a) Horizontal

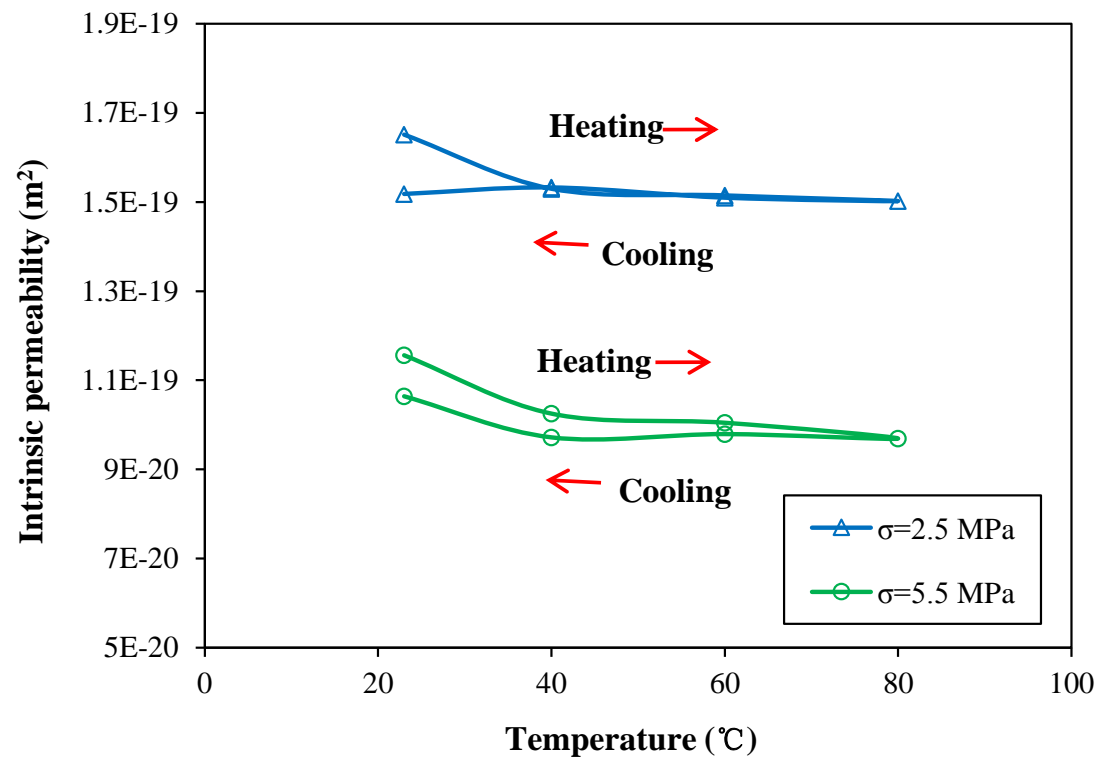

(b) Vertical

Fig. 7 Variation of the intrinsic permeability during heating-cooling cycles 


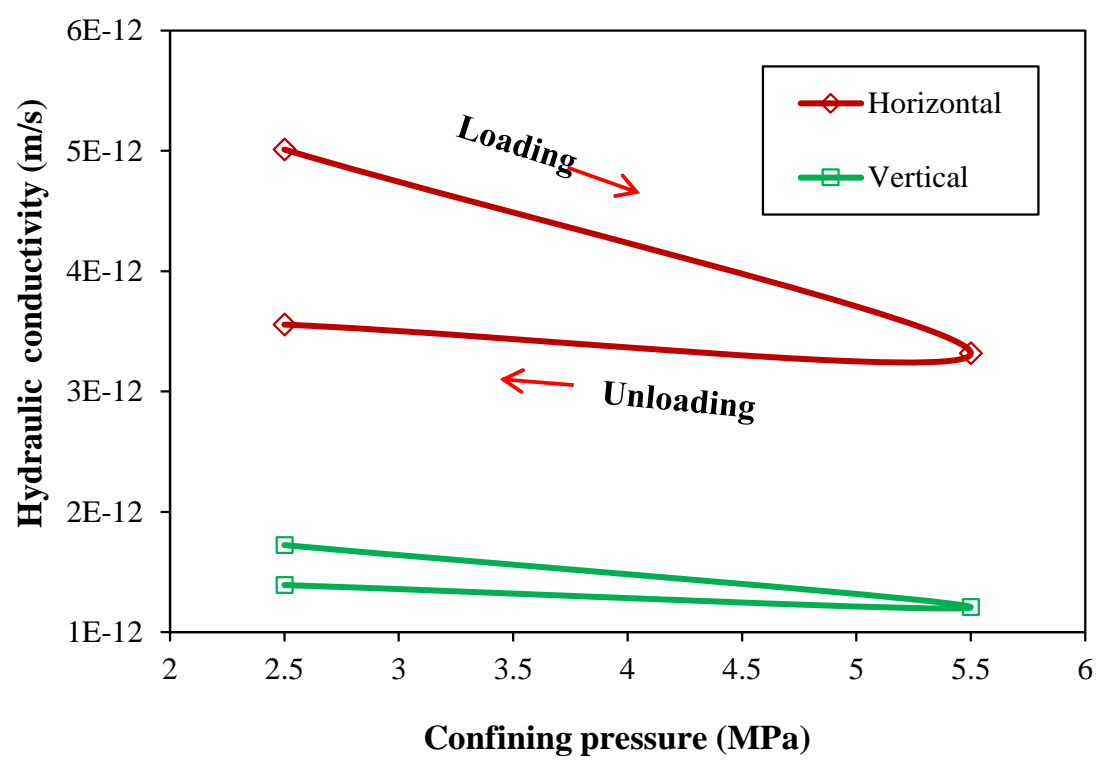

Fig. 8 Variation of the hydraulic conductivity at room temperature during the loading-unloading cycle

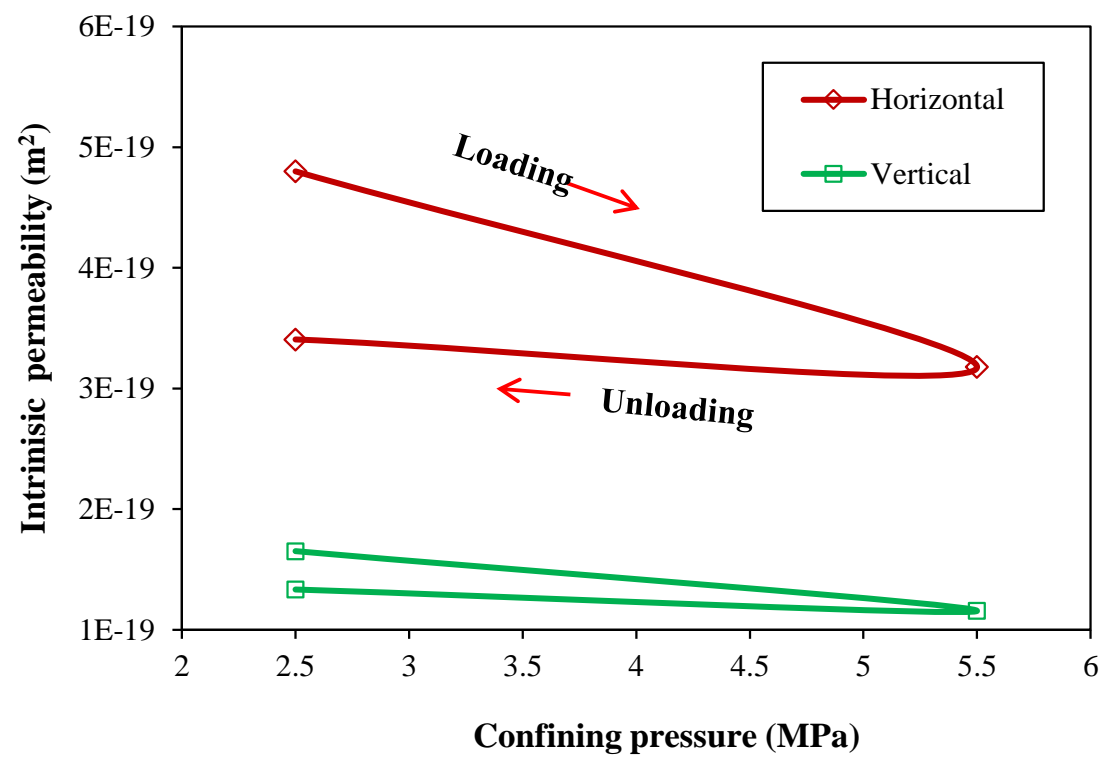

Fig. 9 Variation of the intrinsic permeability at room temperature during the loading-unloading cycle 


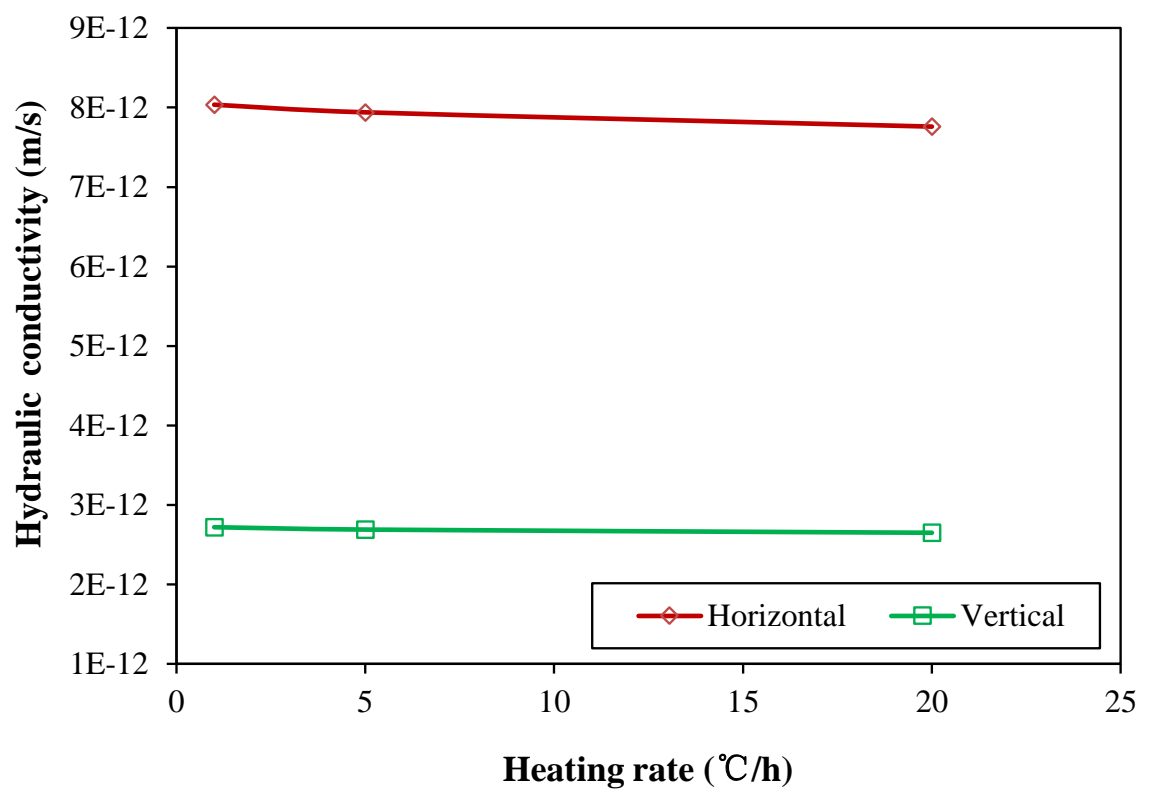

Fig. 10 Variation of the hydraulic conductivity at $80{ }^{\circ} \mathrm{C}$ with different heating rates 


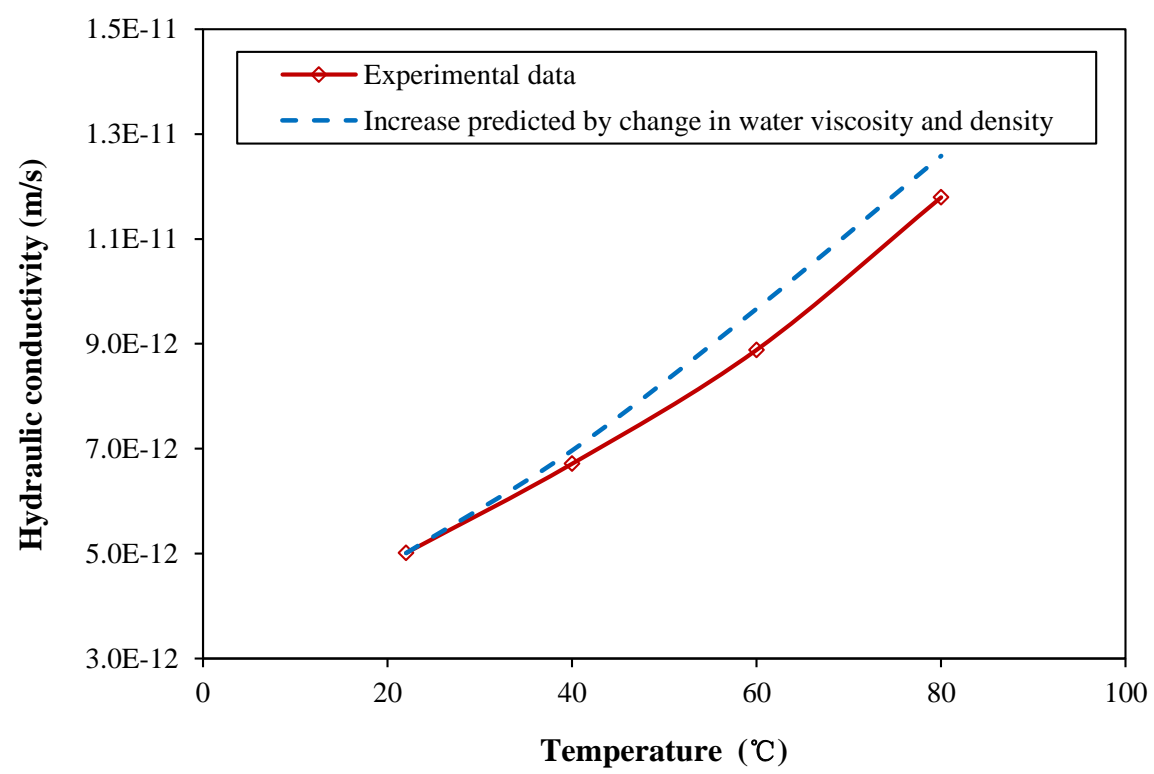

(a) Horizontal, 2.5 MPa

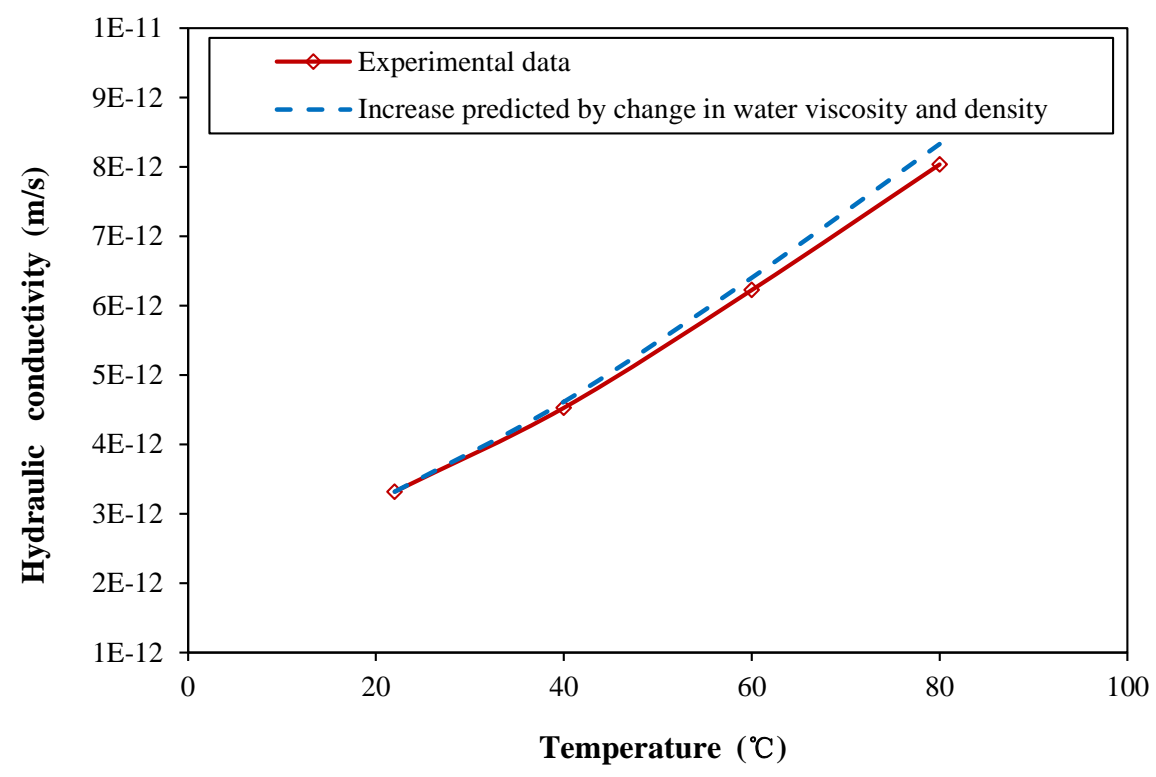

(b) Horizontal, 5.5 MPa 


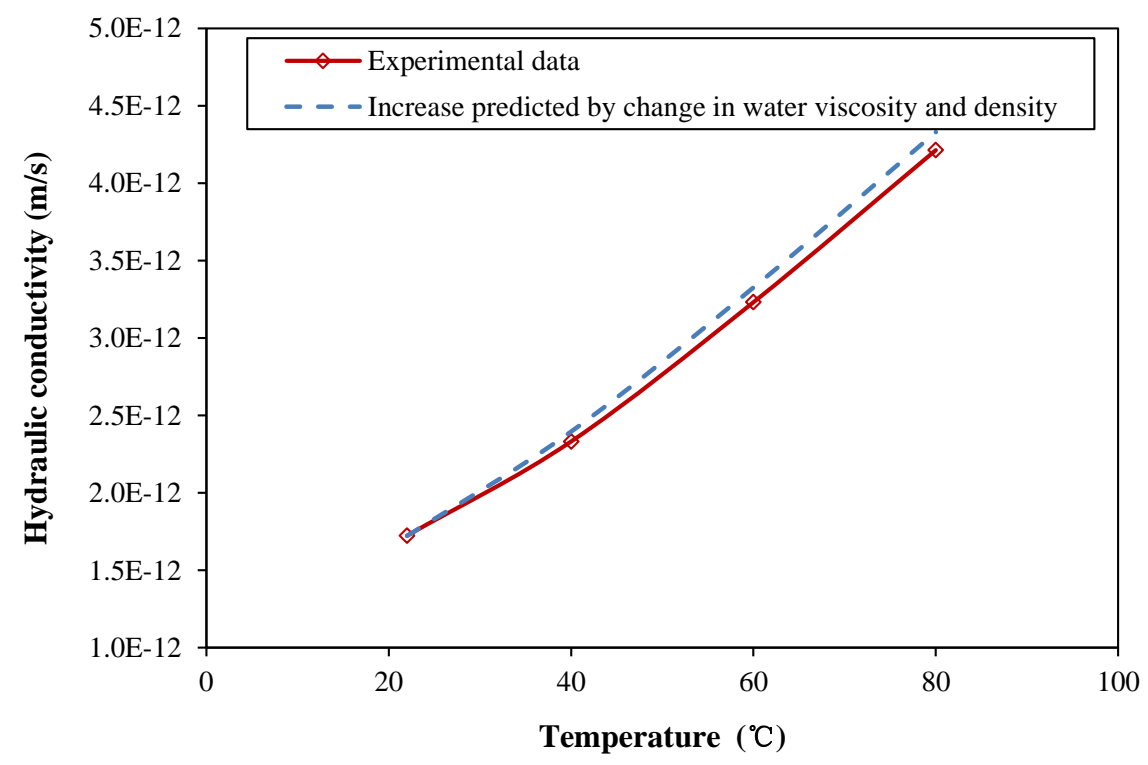

(c) Vertical, 2.5 MPa

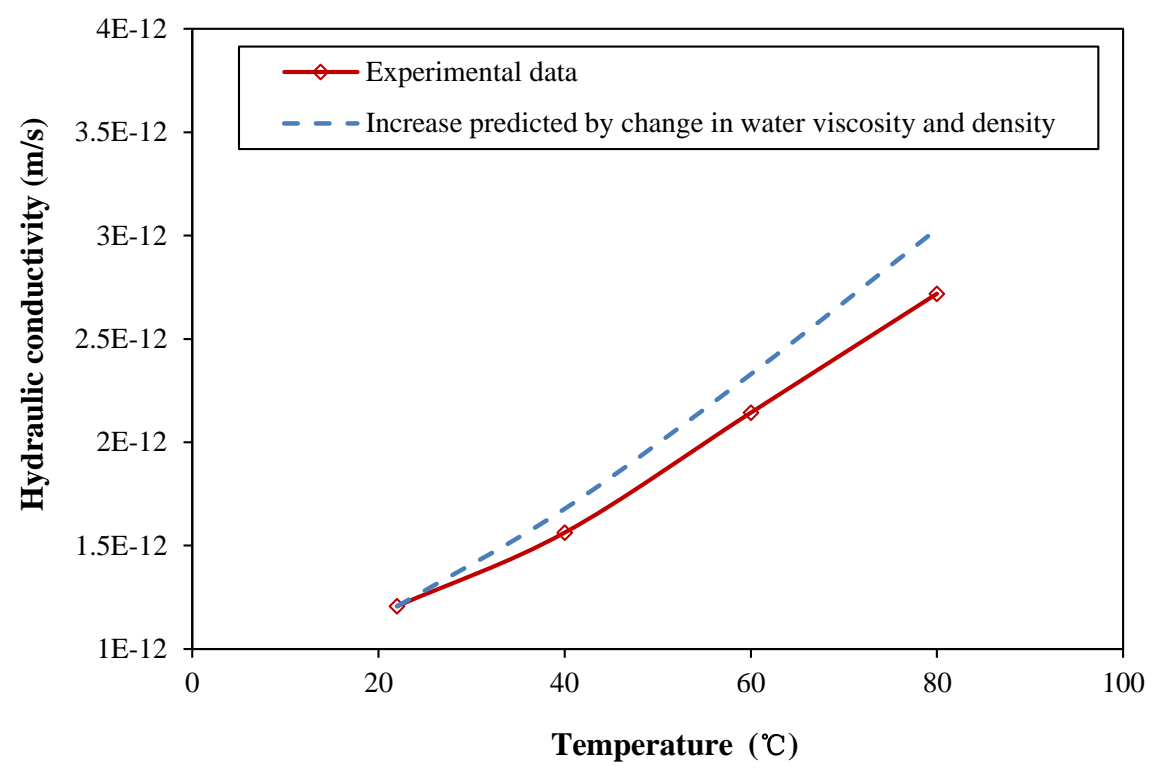

(d) Vertical, 5.5 MPa

Fig. 11 Comparison of the hydraulic conductivity experimentally determined and predicted, only considering the variations of water viscosity and density with temperature changes 


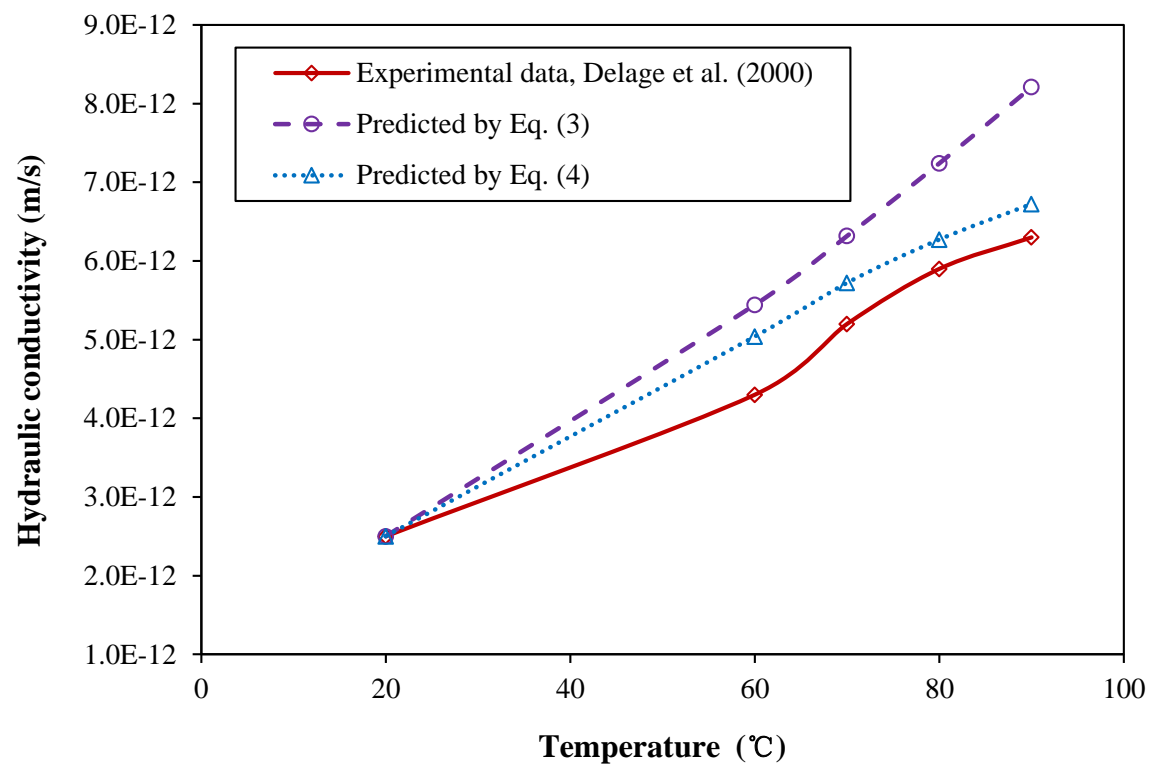

Fig.12 Comparison of the predictions of Eq. (3) and Eq. (4) 